\title{
QUEEN'S
QNEIVERSITY
BELFAST
}

\section{Nonelectoral Participation in Deeply Divided Societies: Transforming Consociations from the Ground Up?}

Agarin, T. (2021). Nonelectoral Participation in Deeply Divided Societies: Transforming Consociations from the Ground Up? Nationalities Papers, 49(2), 344-360. https://doi.org/10.1017/nps.2020.1

\section{Published in:}

Nationalities Papers

\section{Document Version:}

Peer reviewed version

Queen's University Belfast - Research Portal:

Link to publication record in Queen's University Belfast Research Portal

\section{Publisher rights}

Copyright 2020 Association for the Study of Nationalities 2020

This is an open manuscript distributed under a Creative Commons Attribution-NonCommercial-NoDerivs License

(https://creativecommons.org/licenses/by-nc-nd/4.0/), which permits distribution and reproduction for non-commercial purposes, provided the author and source are cited.

\section{General rights}

Copyright for the publications made accessible via the Queen's University Belfast Research Portal is retained by the author(s) and / or other copyright owners and it is a condition of accessing these publications that users recognise and abide by the legal requirements associated with these rights.

Take down policy

The Research Portal is Queen's institutional repository that provides access to Queen's research output. Every effort has been made to ensure that content in the Research Portal does not infringe any person's rights, or applicable UK laws. If you discover content in the Research Portal that you believe breaches copyright or violates any law, please contact openaccess@qub.ac.uk. 


\title{
Nonelectoral Participation in Deeply Divided Societies: Transforming Consociations from the Ground Up?
}

\author{
Dr Timofey Agarin, Queens University Belfast
}

Premised on elite accommodation, consociations provide little consideration for citizens' input on institutional change. Likewise, valuable analyses of cross-community political participation in divided societies have emerged in recent years, yet whether the relationship between the grassroot and formal political process has broader consequences remains to be fully explored. The paper examines the conditions in which nonelectoral participation takes place and the ways in which actors involved therein negotiate constraints for continuous cross-community mobilization. The structure of political system and the nature of deep divisions in Northern Ireland and Federation of Bosnia-Herzegovina invite a comparison of the consequences of nonelectoral political participation in these two illustrative case studies. The paper concludes that while the formal political context shapes the likelihood of engagement on cross-community basis, whether nonelectoral participation changes the structure of political decision-making depends on the willingness and ability of those involved to cooperate with formal institutional politics.

Nonelectoral Participation, Deeply Divided Societies, Consociationalism, Bosnia, Northern Ireland

\section{Introduction}

All polities feature some form of group favoritism, elevating certain groups' status over others, including national citizens, language groups and cultural communities. The relationship between the state and the society it serves is more complicated in deeply divided places, where political institutions are built as essential components for peace and stability to provide for the security of some identity groups but not others. In cases where transition from violence to peace was facilitated by third actors, consociational power-sharing has often emerged as an institution-focused approach to bring political stability for deeply and violently divided societies (Taylor 2009). In countries as diverse as Lebanon, Burundi, Bosnia Herzegovina, Northern Ireland, Macedonia, previously torn by interethnic strife consociational power-sharing structures have played a major role in sustaining peace. To do so, consociational governments mainly include formerly conflicting parties and enable their contribution to governance, "serving a foundation for the future growth of democratic institutions" (Noel 2005, 1). Thus established, such groups are recognized as central to political representation and their identities become ever more salient for political participation. Ethnicity-based representation in consociational politics is believed to indirectly reinforce the principle of ethnic interest formation across society, which makes politicking around cross-community, social issues a divisive undertaking (Agarin 2020). 
Indeed, the analysis to date indicate if mobilization in consociations occurs, it often does so on the basis of ethnic identity issues (Fraenkel 2020; Jusić and Stojanović 2015). Unsurprisingly therefore, the cases of protests in consociations have been treated as exceptions to that rule as analysis tend to foreground the destabilizing effects of (ethno-) political mobilization in divided societies (Nagle 2018a; Byrne 2001).

But there are mobilizations that reach across the ethnic divide and rally on civic issues. The cases of citizen protests in "You Stink" in Lebanon 2015-16 and the "Colorful Revolution" in Macedonia 2016, indicate that (ethnic) identity-based representation is not perceived as an exclusive ground for political participation by some segments of the public (Ceka 2018; Khneisser 2018). Such forms of nonelectoral participation (NEP) are highly visible because they mobilize cross-community constituency. They also have consequences for how consociational optic on politics effects political participation between the electoral cycles. Alongside conventional political participation, that readily drags shared issues onto ethnic terrain and social concerns often become co-opted by the ethno-national agendas, ample space for contention via nonelectoral participation continues to exist in consociations. Citizen participation in nonelectoral contention relies on civic attitudes, individual resources, and mobilization strategies (Verba, Scholzmann and Brady 1995). All of these can translate sporadic outpouring of discontent into organized mobilization in the following phase of "protest cycle" (Tarrow 1989). Both, citizen protests and organizational activity constitute two important avenues for nonelectoral participation in divided societies breaking down - at least temporarily - ethnicity-based political participation and questioning modes of representation entrenched in power-sharing systems.

This paper builds on insights from earlier studies of political participation suggesting that prescriptive inclusion, culture of elite consensus and emphasis on political stability mitigate incentives for change in decision-making structure, as well as focus on the emergent crosscutting issues (van der Meer, van Deth, Scheppers 2009, Verba, Nie, Kim 1978). No doubt, context shapes political participation (Kriesi 2004; Kriesi, Koopmans and Duyvendak 1995), but both formal political process as well as opportunities available for lobbying, organizational involvement and individual engagement are political opportunity structures that shape citizen activism beyond elections (Tarrow 1995; Powell 2000). So, rather than focusing on how well-established ethnically framed concerns are being forced out of institutional politics in consociations or how the marginal (ethnic "other") communities avail 
of institutional openings when reaching the peak of mobilization (Murtagh 2020, Meyer 2004), this paper assesses what happens once protests dissipate.

After hitting the peak of Eisinger's mobilization curve (1973) some cross-ethnic protests translate into organized groups and exert pressure on the formal politics, others demobilize once they meet government neglect or run out of "repertoires of contention" (Tilly 1983, also Della Porta \& Tarrow 1986). The ways in which individuals engaged in NEP perceive and navigate political openings, and the avenues they use to encourage cross-community cooperation, vary depending on distinct social and institutional structures. However different in form, protest action and organizational activity both offer a joint public response to institutional politics via nonelectoral participation. Because in consociations political institutions neglect, political elites highjack and policy processes marginalize civic, i.e. nonethnic issues from the reform agenda, careful coordination is required of steps following the street protests to navigate constraints of power-sharing politics. Notwithstanding, NEP calls upon political decision-makers to reflect the wider array of the interests in society; and specific to consociations, it underscores the importance of cross-cutting issues that are yet to gain political salience on par with those presumed to be immanent to groups pivoted to share power after conflict.

This paper's focus is on nonelectoral political participation in divided societies as the prime locus of citizen interaction on shared agendas unconstrained by group-based formal political participation. Using the contrasting examples of FBIH and NI the paper reflects on forms that NEP ought to take in order to ensure there are political consequences of cross-group cooperation in power-sharing settings. The paper traces what happens once noninstitutionalised movements face the slow grinding of political process. To achieve that, it maps the original concerns of citizens engaged in cross-community activities to see how these feed-forward into political participation after the street protests as NEP takes on an organised form. Overall, the conceptual apparatus used here accounts for non-electoral participation that is ultimately about issues with considerable political salience and which can be effectively translated into political decision-making and possibly institutional reform. The core argument thus is about the effects of nonelectoral participation on the structure of political decision-making in consociations: It suggests that NEP which fails to maintain cross-community cooperation after the peak of protest and re-organize cooperation into that of NGOs, interest groups' coalitions, and alliances is likely to see limited lasting legacy in the settings of formal politics. The analysis of the dynamics in non-electoral participation allows 
us to establish the overriding importance of changing track from protest to organisational activity, the key finding of this paper.

The presentation is organized as a sequence of conceptual arguments and empirical evidence. Firstly, we revise the literature on political participation in divided societies to identify the facilitating conditions for organizational activities that seek to go beyond the salient zero-sum game of ethnopolitical mobilization. Then, we sketch the institutional environment for nonelectoral participation by assessing the structure of decision-making in power-sharing systems. Third, we explore the evolution of cross-community mobilizations in two consociations and the ways in which NEPs maintained relevance for political decisionmaking in Northern Ireland and Federation of Bosnia and Herzegovina. A discussion section concludes.

\section{Political Participation in Divided Societies}

Where the elected representatives advance the exclusive interests of the constituency that shares their primarily identity, members of that community perceive greater opportunities to attain influence over political outcomes on the basis of their identities, rather than by bridging identity divides (Bieber 2004; Hartzell and Hoddie 2003). This is often the case in powersharing political systems, where the perception that political representation is most effective when individuals from certain identity groups speak on behalf of their "own" people. The classic model of consociational power-sharing proposed by Arendt Lijphart (1977) demands the management of conflict in society through inclusion of the main (ethnic) groups within government and their sharing of power. Resting on the principle of elite accommodation and representation of (ethnic) groups via their leaders, it evidently accords little role for bottomup mobilization of citizens in politics. Because politics in consociational settings is particularly elite-centric (Murtagh 2015), issues that are cross-cutting or unrelated to ethnic identity usually lack representation in high-table politics (Sircar 2019; Luther and Deschouwer 1999). Cross-group mobilization challenging political decision-making is oftentimes sporadic because every issue is dragged into the ethnic terrain (Fraenkel 2020; Horowitz 1985).

Thus, the relationship between cross-community political participation and consociational power-sharing is found to be ambiguous. On the one hand, political mobilization strengthens political regime horizontally as it galvanizes the "political participatory ethos" of individuals 
(Glenn 2003; Nagle 2018). Protests that bring to fore the interests shared across groups play an important role in asserting that institutions are accountable to all segments of consociational society. Once participation crystallizes into organizational membership, these groups can robustly challenge state institutions, inform political elites about the issues underpinning the societal mobilization and vocalize the need for political change in the formal institutional context. On the other hand, the scholarly views on political mobilization underline its goal-oriented nature (See, e.g. Verba, Nie, Kim 1978; Kitschlet 1986; Pickvance 1999). Thus, citizen participation takes cues from the existing structure of political decisionmaking which provides incentives, opportunities, and outlets for mobilization to confirm to, or reform the existing criteria for redistribution of available social, economic and political resources (Bojicic-Dzelilovic, Ker-Lindsay, and Kostovicova 2013; Beichelt et al. 2014; Di Palma 1991).

Political elites and citizens alike make consociational institutions work. Both groups benefit from inclusion of "their" representatives in government, guarantees of group autonomy, veto rights, and proportionate representation (McCulloch 2014). Citizens making a choice of political elites therefore are incentivized to accept the underlying logic of group-based political representation. Few political entrepreneurs would run the risk of promoting policies and pioneering institutional reform to make the state more civic, i.e. less responsive to the narrower politically relevant identity of their (ethnic) constituencies. The context of divided societies additionally encourages competition between identity groups outside of the electoral process following the ascriptive ethnic ties that have generated an antagonistic segmentation of society (Nagle and Clancy 2012, 92). In short, individuals choose, both as subjects and objects of the formal political process to subordinate some of their cultural, social, and civic identities, and related interests, to those that have greater salience in the institutionalized politics. This means that sustained political cooperation across group boundaries is particularly difficult in deeply divided societies operating under consociational rules because of their limited "political openness" (Eisinger 1973). Consociational polity might be sufficiently tolerant of civic protests vocalizing citizens' needs, avoiding confrontation or repression (McFaul and Treyger 2004). Yet, it is unlikely to assimilate the proposed alternative political agendas and even respond to citizen input because these question the efficacy of existing political arrangements and could upset the carefully balanced representation of identity-based political constituencies. 
The analysis of nonelectoral participation (NEP) in deeply divided places tends to echo those about the practices of political elites in such states. This points to the unique nature of relations between consociational institutions that represent some (ethnic) groups and crosscommunity NEP that seek to articulate (putative) interests of the citizenry as a whole. The potential of nonelectoral mobilization to reshape who and how state institutions serve without challenging the very existence of the state (at least initially) is central to this.

The NEP demonstrates that issue-based cooperation is possible even in divided societies and consociational settings. Citizens otherwise competing for access to political institutions can negotiate shared concerns on bread-and-butter issues, bring together the previously separated communities and incur benefit for citizenry at large. Such participation can draw upon identity groups that constitute a fraction of the population; who are underrepresented because their primary ascriptive socially relevant identity is one other than ethnicity, for example centered on gender or sexuality; and those who disconnect their social and ethnic identities from their political identities and seek representation in keeping with liberal, individualist notions of liberal democracy (Stojanović 2017; Agarin, McCulloch, and Murtagh 2018). Cross-community NEP therefore obviates the institutionalized constrains for group-focused political representation shaped by ethnic identity, explicitly including "other" interests, those not inscribed in the elite and ethnic group structure of power-sharing government.

Citizen contention is the key indicator of public dissatisfaction with the efficiency of political decision-making in divided societies and some protests drawing cross-community support in consociations have drawn some scholarly attention. This may appear unsurprising given the overwhelming concern about political stability which consociational systems ought to maintain and the received belief that any mobilization is disrupting the fragile peace in divided places. Yet, civic mobilisations that take cues from protests feature in studies of political participation in deeply divided societies (Murtagh 2015; Kurtović and Hromadžić 2017; Nagle and Fakhoury 2018; Pollozhani 2016). But these studies frequently focus on protest dynamics and its aftermath, pinpointing the challenge of viewing sporadic outpourings of citizens' discontent in the street as preludes to formal engagement with political strategies. Most discussions provide an assessment of what protests achieve, neglecting analysis of consequences for cross-community participation in consociations (See Lai 2019 as an exception). This is rather surprising given the objective of people involved in NEP to prioritize socially relevant issues and change the primary reference point for 
individuals' political engagement from (ethnic) identity-based to the one focused on interests and issues.

For example, in relation to Lebanon's "You Stink" and North Macedonia's "Colorful Revolution" studies offer retrospective analyses of factors internal to protests, mainly focusing on popular response to stasis in institutional politics (Bogaards 2019; Piacentini 2019). The attention to dynamics of protests has delivered post factum examinations of mobilization from perspectives of strategic interaction (Jasper and Duyvendak 2015) and strategic action field (Fligstein and McAdam 2015). Most analysts implicitly agree with Kitschelt (1986) that altered states' input structures and output capacity shaped protest mobilization. Three key aspects have been used to explain collective mobilization in the above cases adding somewhat to understanding of protests' timing, causes, and effects. First, the shared view of and access to the repertoires for action which allow contention to target the known and accessible "set of political actors" (Tarrow and Tilly 2007, 11). Second, the frames of collective action offer "schemata of interpretation" for participants of protests to identify, translate, and internalize the events external to their personal experiences into their own social contexts (Johnston and Noakes 2005; Benford and Snow 2000). Finally, the persistent identity of actors involved in the contention that allows maintenance of the model of organization over time (Polletta and Jasper 2001; Bosi and De Fazio 2017). All of these aspects posit that at least some of the social structural elements, particularly group-formative grievances, remained stable over time. The studies of protests in, e.g. Lebanon and North Macedonia assess ways in which the underlying blockage of decision-making in powersharing systems has encouraged street protests. Yet, we miss conclusion that go beyond "blaming the (consociational) system" and outline consequences for cross-community political participation in protests' aftermath.

Nonelectoral participation (NEP) in divided societies offers forums for individuals of competing identity backgrounds to cooperate and engage with the institutionalized forms of political representation. Ultimately, protests are different from electoral political participation in that their institutional effects are impossible to measure directly; to begin doing so we need first to focus on the phase when mobilization takes on institutionalised form and assess the organizational avenues that (can) change the conditions facilitating political participation. NEP is thus the prime avenue for projecting concerns that are socially relevant but which have not been recognized as such in the domain of formal consociational politics. We focus on NEPs, expressed reason for mobilization, and consequences of political participation for 
the overall structure of decision-making in formal, i.e. electoral politics. Building upon past scholarship, we identify two sets of questions. The first concerns NEPs' conditions: How does NEP navigate societal barriers and political neglect of the power-sharing system? Below we explore the strategic choices they make in order to impact public perceptions about crosscommunity participation. The second question relates to NEP's consequences for structure of political decision-making: Have NEPs sought to and possibly affected change in modes of formal political participation in deeply divided societies that host power-sharing systems? We assess these objectives at both the societal and the political levels by focusing on institutionalized channels that propel interests into the societal arena on a civic platform; this allows us to put organizational activity in power-sharing settings and its consequences for participation in the context of their members' original expectations. This paper offers a comparative analysis of NEPs consequences for participation in two deeply divided societies where consociational power-sharing has been implemented.

\section{Institutional Context}

Out of the universe of consociational systems, we have selected Northern Ireland (NI) and Federation of Bosnia and Herzegovina $(\mathrm{FBiH})$, two regions where power-sharing is in place to manage ethnically diverse societies with deep-seated, socially relevant identities. Largely due to the relatively recent peace after ethnic conflict, perceptions about the significance of ethnic identity for political participation are reflected in both political and interpersonal interactions of citizens in NI and FBiH. Further, ethnic structure in both societies is bi-polar (Protestant/Catholic and Bosniak/Croat) though other ethnically salient identities are present, in part as a result of both $\mathrm{NI}$ and $\mathrm{FBiH}$ being part of the a wider state, the $\mathrm{UK}$ and $\mathrm{BiH}$. Unlike the cases of Lebanon and North Macedonia, state-wide consociations, both NI and $\mathrm{FBiH}$ are substate entities additionally challenging leverage over political consequences of participation for the structure of electoral decision-making. However, in substate entities, the change in the "risk — reward" ratio (Oberschall 1973, 163) can be assessed more accurately by those choosing NEP over formal political participation to identify opportunities to challenge decision-making structures as the consequence.

The 1995 Dayton Peace Agreement created a constitution for the post-war BosniaHerzegovina, setting out political arrangements for rigid consociational power-sharing between the three parties to the conflict, termed the "constituent peoples": Bosniaks, Croats and Serbs. This arrangement, approximating a corporate form of consociation, included a mix 
of ethnic and territorial power-sharing (McCulloch 2014). Dayton enshrined extensive veto rights for each group, including a "vital national interest" veto and so-called "entity veto" in the state parliament (McEvoy 2014). From its inception, this system has been roundly criticized by the international community for its dysfunction - prone to deadlock given the permissive veto regime, - its entrenchment of ethnic division, and its discrimination against those who do not identify with any of the three constituent peoples. Indeed, the European Court of Human Rights has now ruled on three occasions against the state of $\mathrm{BiH}$ for violating the rights of non-constituent peoples by preventing them from participating in state elections on an equal basis, most notably in the landmark Sejdić and Finci (2009), Zornić (2014) and Pilav (2016) (Graziadei 2016). Nevertheless, despite numerous legal and political statements urging constitutional revision that would address this discrimination, dysfunction and ethnic division in the system has thus far eluded reform.

Considerable territorial autonomy was granted to each group through the creation of a weak central state and two federal entities: the Serb-dominated Republika Srpska (RS) and the Bosniak-Croat Federation of Bosnia and Herzegovina (FBiH), the latter further decentralized into ten cantons (Bieber 2006). The system of representation features proportional representation of the three groups through ethnic quotas for positions in the legislature, executive, judiciary and public administration. At the state level a rotating three-member Presidency and the reserved seats in the upper house of the parliament allows for individuals identifying with one of the three "constituent peoples" to access these posts (Keil 2013). However, while RS is largely Serb populated, the FBiH is mixed entity of ten cantons, each governed by the parliaments (assemblies) directly elected using proportional representation mechanisms. This ensures dominance of either Bosniak, or Croat political elites, and their interests, over the five year tenure of cantonal parliaments.

Likewise, "peace process" in Northern Ireland (NI) culminated in the 1998 Good Friday Agreement, putting in place political system to accommodate two (ethnic) groups involved in past violence, Protestant Unionists and Catholic Nationalists. The consociational powersharing framework features protections and guarantees for each community, such as proportional representation in the legislative and executive, and a veto over matters perceived to threaten their communal interests. To this end, Members of the Northern Ireland Assembly are required to designate as "Nationalist", "Unionist" or "Other" with votes on certain key issues requiring cross-community support, through "weighted majority" or "parallel consent". In such instances, the votes of "Others" - who in the current Assembly include "socialists", 
"environmentalist", and "European" - do not count on an equal basis to Unionists and Nationalists (Standing Orders, 2013). The vote on key issues can also be triggered by a "Petition of Concern" signed by 30 Members, which functions as an effective group veto. Structured around the principle of community representation, this system affords limited space to actors identifying as "Others" and mobilizing on a non-communal basis (O'Flynn 2003), for cross-community political parties and cross-cutting alliances and political movements (Murtagh 2020; Mitchell 2018).

Post-agreement power-sharing in NI has veered from crisis to stability and back again. Following several suspensions of the institutions in their early years, the 2006 St Andrews Agreement paved the way for ten years of uninterrupted power-sharing from 2007 to 2017 , during which contentious justice and policing powers were devolved from Westminster in 2010. Since 2006 the transitional phase of politics in NI has witnessed a discernible shift in focus: from issues relating to peace and security, towards amplification of "moral" debates in politics (Evans and Tonge 2016). Tensions between coalition partners, the unionist Democratic Unionist Party (DUP) and the nationalist Sinn Fein (SF), were more the norm than the exception. Ultimately, the corruption scandal in which the DUP leader was embroiled triggered the collapse of power-sharing in January 2017. The suspension of the Assembly continues after several rounds of negotiations have failed to reinstate formal cooperation of DUP and SF. Underlying the deadlock in negotiations is the DUP's reluctance to initiate the legal review of occasions when veto can be triggered, as proposed by the overwhelming majority of parties currently represented in the Assembly. This dispute deepens political divisions over social issues, such as the legalization of same-sex marriage, that have been framed as "community relevant" by the SF and to which the DUP remains opposed.

Consociational systems in both NI and FBiH encourage ethnic alignment between the voters and their representatives, with political participation taking place against the background of representation that is identity based, or is at least perceived to be based, around identity categories. As a result, in both $\mathrm{NI}$ and $\mathrm{FBiH}$ politics are marked by ethno-national polarization, ethnic clientelism, and low public trust (Touquet 2015; Puljek-Shank and Verkoren 2017; Mitchell 2018). NI as part of the UK, features a more flexible, "liberal" form of power-sharing in which the groups that share power are not mandated in the constitution but determined through the electoral process. In $\mathrm{FBiH}$, as part of $\mathrm{BiH}$, we see a more rigid, ethnicized and "corporate" form, in which the groups specified in the Constitution are 
afforded quotas for their representatives (McCulloch, 2014). In these settings electoral participation is centered around ethnic categories, which maintain relevance throughout formal political channels as they ensure guaranteed representation of interests not on the basis of citizen, but group identity.

Citizens' interpretation of the opportunities for electoral participation along the group-lines is also acknowledged to limit bridge-building and cooperation in NEP. The NEP, however, is not pre-determined by consociational political institutions, allows articulation of political agency outside of ethnic silos, and fosters social interaction across group boundaries. Both NI and $\mathrm{FBiH}$ societies have witnessed significant nonelectoral cross-community mobilization in recent years: campaigns for equal marriage and abortion rights in NI, and the protest and plenum movements in $\mathrm{FBiH}$. In both cases, citizens involved in NEP implicitly and explicitly questioned the impact of groupist design on formal political participation and representation of others' interests. The organizational mobilizations bridged differences between the politically salient groups despite the background of political structures that discourage inputs not based on identity. Overall, citizens contention that not only group-based concerns are politically relevant laid at the heart of nonelectoral participation in both cases.

On the one hand, the NEP affords avenues to citizens of all identity groups to point out the importance of interest-based representation to politicians outside, or in parallel to, electoral cycles. On the other hand, particularly in political institutional settings with weak capacity to serve all segments of deeply divided societies, NEP challenges the narrative that only policy issues that affect groups' (core) identity are political sensu strictu. Protests around the issue of access to abortion and equal marriage in Northern Ireland, or issues of social welfare in Bosnia are such sets of concerns affecting all citizens of these consociations.

In the following, the contrasting examples of one case of NEP per country, and during a specific period of that NEP's activity showcases what form does nonelectoral participation ought to take in order to maintain cross-group cooperation in consociational settings. The focus on NEP - rather than specific instances of protest mobilization or organizational activity - pinpoints that political behaviour does not need to align with group identity, or with "openings" of the formal political process. We are aware that NEP in our two cases might be perceived as incompatible: The Yugoslav plenums are said to have offered one of the options on the "repertoire of contention" (Kurtović and Hromadžić 2017), while political success of Northern Ireland Women's Coalition continues to inspire cross-ethnic cooperation (Kennedy, Pierson, and Thomson 2016). And yet now, formally democratic institutions 
structure the contemporary political process and obviate the explanatory power of long-haul societal processes, such as legacies of the past. While Plenums in FBiH offered individuals an opportunity to partake in decision-making outside formal political process, the organized groups in NI have lobbied established political parties in the Province and in the Westminster Parliament, and sought support from global networks of NGOs. However, from the internal agenda-setting perspective both plenums in $\mathrm{FBiH}$ and marriage equality movement in NI fostered wider links and partnerships "across the divide" to facilitate participation. This allows us to look at conditions for participation in both, rather than at their individual goals or of those publics involved. In doing so, we are able to outline consequences of NEP for formal political participation rather than to claim whether outcomes map well onto the goals originally set in each of these. This paper's focus is on agents' own and persistent commitment to broadening participation in consociations; it compares the consequences for the choice of NEP strategies, not for its origins or process.

The discussion below is based on document and literature analysis, and around 30 semistructured, narrative interviews with civil society activists in both NI (2018) and FBiH (2014). During fieldwork interviews we have sought to understand the strategies of protest and organized mobilization, nature of the campaigns, their aims, timing and duration, and asked our interview partners to assess their impact on formal political process. While the paper does not draw equivalence between the two cases of NEP, it offers reflection on the details intimated to us during the interviews as (potentially unrepresentative, but informative) sample of views by those closely involved about the impact of nonelectoral participation can have on formal political process. The comparison is useful in the context of deeply divided societies allowing a clearer view on mechanisms translating cross-community discontent into participation outside formal politics.

\section{Bosnia’s Plenums}

Against a backdrop of perceived political dysfunctionality, a series of mass protests known as the "Baby Revolution" (Kurtović 2018; Armakolas and Maksimovic 2013) emerged in the summer of 2013 in Bosnia and Herzegovina. The protestors demonstrated to draw attention to the problems with the allocation of citizen registration numbers allowing for travel to access medical treatment abroad. When these protests abated, another wave of NEP in the following 2014 led to a series of events commonly referred to as the "plenum movement" spanning 
several localities across the country in a relatively short period of time (Belyaeva 2017; Milan 2017). Igniting in the north-eastern industrial city of Tuzla in response to the closure of factories following their allegedly corrupt privatization, the movement quickly broadened in scope to address wider social and economic grievances and spread to a number of other cities and towns (primarily) in the FBiH, including Sarajevo, Mostar, Zenica and Bihać. It emerged as an outpouring of frustration at the conditions of life in Bosnia, including widespread poverty, high unemployment and the failure to address those ills by a political class perceived as corrupt and system viewed as dysfunctional (Lai 2019; Mujkić 2014).

The 2014 plenum movement was framed in terms of social justice and civic democratic accountability with slogans including "We are hungry in three languages" (Arsenijević 2014). Alongside street protests, citizens' assemblies ("plenums") were formed to channel popular discontent into forms of organized representation. Citizens involved therein debated and voted on demands which were then put forward to political authorities - primarily at the level of canton and local municipality in the FBiH entity (Riding 2018). Plenums therefore sifted through, organized and formalized citizens' demands, including calls for resignations, revision of allegedly corrupt privatizations, cuts to excessive benefits for politicians and the installation of expert governments. In response to the spread of plenums activity, four cantonal governments resigned and some agreed to end certain benefits and privileges for political representatives, while a technocratic government was installed in Tuzla canton (Milan 2018). Nevertheless, after some three months the momentum was lost and the movement dissipated in May 2014.

Accounts argue that spontaneous emergence of the protest and later, plenum movement channelled citizens' frustrations illustrating the blockage within the Bosnian consociational system to the advancement of non-ethnic issues (Kurtović 2018). Moreover, the street-based protest of 2013 has only been part-translated into alternative political structures of citizen assembly, a phenomenon Eric Gordy refers to as "alterpolitics" (2015). Both protest and later plenums shared the view that conventional political participation lacked ability to gain listening from and communicate citizens' needs to policymakers, rejecting interaction with the existing institutions of the state. Mujkić articulates, somewhat exultantly that, “...discontented citizens in February 2014, realizing that the existing institutions and procedures of parliamentary democracy were corrupt and highly inefficient, managed to forge a new institution - an institution of direct democracy - the Plenum - as an open ended civic 
forum to include the vast plurality of citizenry gathered by their concern about the common good that was thoroughly debated" (2014b).

Bosnia's consociational framework afforded NEP limited openings and severe constraints, including co-optation and intimidation by the established ethno-national political parties. These attempted to ethnicize, divide and delegitimize both the protests and plenums (Mujkić 2014a), with Serb and Croat elites claiming it was orchestrated against their people and painting it as a solely Bosniak affair (Balkanist, 2014; Touquet 2015). Meanwhile, activists reported bids by Bosniak parties to co-opt the plenums for their own electoral advantage (Hasić and Karabegović 2018; Murtagh 2016). Others describe active intimidation by ethnonationalist parties to stave off the action, including by Croat parties towards Croat activists in the mixed Croat-Bosniak city of Mostar where their participation in the movement tapered off as a result (Forde 2016). Activists in the Mostar Plenum and protests remarked that only intra-ethnic intimidation was exercised by political representatives (Murtagh 2016, 160).

At least some activists were acutely alert to threats of cooptation, developing strategies to avoid ethnicization and opting to engage only minimally with formal politics. Leaders of plenums chose not to form a political party, nor alliances with parties, nor even to lobby these actors. They have also shied away from pacting with NGOs or international actors. One Sarajevo plenum organizer reported: "The mention of the possibility of forming anything related to a political party makes people angry, infuriated, screaming and threatening to leave" (cited in Murtagh, 2016, 161). Rather than challenging the perceived distinctness of movement from party politics in relation to social issues, plenums have precluded input into formally political channels setting them apart from contemporaneous, similarly framed social justice movements in the South European states (Della Porta et al, 2017).

The Bosnian protest movement recoiled from engaging with party politics, but at the followon stage of NEP, plenums too refrained from entering debate on constitutional reform which would have allowed building NGO alliances. One Tuzla plenum organizer notes that "the constitutional reform is not an issue. We did not draft the constitution and we are not going to change it either. The focus is on how people live, daily - health, education, jobs" (Cited in Murtagh 2016, 162). Plenums therefore impacted how some concerns of citizens were represented but did so at a local level of municipalities or cantons: While some cooperation between citizen assemblies across $\mathrm{FBiH}$ took place, there was markedly limited progress in extending horizontally, from FBiH to Republika Srpska, or vertically, to inputting debates on 
representation at the state level (Kurtović 2018). The limited engagement at the state level, across the entity borders of FBiH and Republika Srpska, and even across cantonal borders further points to the adverse impact the multiplied policy-making arenas have on citizens' perceptions of NEP as sensible (Vrablikova 2014).

The plenum movement had a number of discernible short-term effects on formal, institutional politics in $\mathrm{FBiH}$, including triggering cantonal political resignations and creating a new nonethnic independent trade union, Sindikat Solidarnosti (Union of Solidarity). Some activists describe the movement's greatest achievement as civic engagement and the raising of civic consciousness in the post-war state, as citizens "woke up" after almost two decades of depoliticization. As one activist expressed: "In Mostar where you have the divided society for so many years... Croats and Bosniaks [were] together on the protests, together on the plenums. ... For the first time it's not ethnos, it's demos. In this country, with this kind of political arrangement, I think that's a really huge step forward" (cited in Murtagh, 2016, 165). It would be fair to say that the plenums have sought to change primarily access points for citizens participation in and engagement with bread-and-butter issues eying potential institutional reforms of state institutions. However, plenums remained locally active with little coordinating capacity to craft cross-community platform acceptable to parties in the ethnicized political system at the FBiH and BIH as a whole (Sircar 2019). Failing to swing the opinion of the plurality of voters and their political leaders about the need for reforming the system of political representation has not been the result of plenums' lack of effort, however. Rather, in fielding suggestions about reform, plenums went either too high or too low: demanding ambitious institutional change to the system of representation that required constitutional reform and consent of the cross-community majorities, or pointing to individual cases of political corruption and office abuse leading to personnel reshuffling but were hardly credited to NEP via plenums.

\section{Northern Ireland's Equal Marriage}

In NI, public protests on LGBTQ, gender and reproductive rights mark clear instances of cross-community mobilization (Thomson 2016). As abortion remains illegal in Northern Ireland in all but exceptional circumstances, there has been growing overlap in NEP around the three issues prevalent in Northern Ireland today: marriage equality, abortion rights and Irish language rights - and a contagion between them in terms of their frames and strategies. 
Since first Belfast Pride in 1991, eight years after the decriminalisation of homosexual acts in the Province, (non-festive) rallies have regularly been organized by LGBTQ activists highlighting persistence of homophobia in NI. These events have been rare occasions for cooperation between both NI communities, Protestant and Catholic in the decade prior to Good Friday Agreement (GFA). Their cross-community, bottom-up approach to ensuring continuous visibility in the public space was the only option, because LGBTQ issues have “... been traditionally shut out of the corridors of power, our campaigning has been streetbased campaigning, about visibility" (Representative of LGBTQ Advocacy Group, 2018).

Regardless, of continuous visibility, cross-community engagement and cross-border cooperation on the island, Northern Ireland stands as the only part of the UK or Ireland where same sex marriage is still prohibited by law. Equal marriage legislation has been put forward on five occasions in the Northern Ireland Assembly but so far failed to pass, with the Petition of Concern used each time to block these motions, most recently by the DUP in November 2015. Against this backdrop, the campaign Love Equality was formally established in 2015 as a consortium of organizations campaigning for the introduction of legislation for equal civil marriage. The issue has risen steadily to prominence in the past years, when nationalist party SF cited it as one of the reasons for its withdrawal from power-sharing government with the unionist DUP (Irish Times 2017).

Over the past decade, civic groups have mounted pressure on the devolved Northern Ireland Assembly and Executive and, more recently amidst their suspension, on the UK Government to legislate directly on equal marriage to NI. In the absence of a functioning Assembly and the progression of legislation unlikely as long as the DUP is the strongest party, civic advocacy groups have increasingly turned to other forms of political activism. NEP has taken on greater significance, as one representative of LGBTQ group suggests because the battle for marriage equality had been "won... years ago". In terms of public and political support, $68 \%$ of respondents supporting legalization in a 2018 poll (Northern Ireland Life and Times Survey, 2018) and a majority of currently elected Members of the Legislative Assembly support legislative change in principle.

Yet, the design of the power-sharing institutions is preventing that support translating into legislation. LGBTQ activists lament the lack of progress on human rights issues delivered under power-sharing in general, but particularly those relating to gender and sexuality, which have advanced furthest during periods of power-sharing suspension and direct rule from 
Westminster (Nagle 2018b). One activist identified the continual instability of the powersharing institutions as a barrier to progress in political development: “... the biggest frustration and the biggest criticism I can really put to the Northern Ireland Assembly is that I don't miss it." (Representative of LGBTQ Advocacy Group, 2018).

We have identified that plenums in $\mathrm{FBiH}$ sought to mobilize on their own platform. Given the threat of co-optation that their engagement with political elites might entail, their strategic choice was to disengage from formal politics altogether (political issues, institutions and actors). In NI too, political engagement was equally highly considered with activists likewise mindful of the risks of contestation and the need to develop strategies to avoid co-optation. Given the championing of the marriage equality agenda by SF and its opposition by the DUP, the marriage equality movement has been careful in its public relations strategy not to be seen to side with the former, including openly criticizing the party where they felt it was due. For this reason, in the 2018 party talks to resuscitate power-sharing the campaign explicitly refrained from calling on SF to hold passage of marriage equality legislation up as a "red line" condition for re-entering power-sharing with the DUP and restoring the institutions. "[We] have been determined not to be captured by a particular political party or one side of the Green-Orange [Nationalist-Unionist] divide.” (Representative of Human Rights Group, 2018). In fact, representatives of advocacy groups intimated that they sought to do “absolutely everything” to prevent LGBTQ issues from being seen through a party-political prism, precisely because these issues are tangent on existing divisions in society.

To do so, activists organized in neutral locations and avoided associations with one community over the other. Given the historic association between issues of inclusion and nationalist/Republican activism in NI, one LGBTQ association spoke of the importance of having presence and outreach on both sides of the river in the city of Derry/Londonderry, i.e. bridging the physical border dividing the two ethnic communities. Critically, as we have heard multiple times from the interviewees, the movement's goal was not just to ensure change in the legislation but to usher in the broader transformation of social attitudes around LGBTQ issues, a goal easier to attain once identity yields space to issue-based politics.

Similarly to FBiH plenums, NEP around the LGBTQ issues sought to contribute to broader political change engaging citizens in nonelectoral activities. However, the marriage equality alliance in Northern Ireland has chosen a different strategy: It was transformed and was led by the NGOs and sought direct engagement with community groups, as well as with the 
institutions and parties of high politics. Unlike their FBiH counterparts, NI activists have engaged directly with the national, UK Parliament reaching out to MPs from across parties, effectively by-passing the devolved institutions blocked by presence of the veto player, DUP. As a result, the UK Parliament has successfully voted on 9 July 2019 for the legislation extending same-sex marriage to Northern Ireland in the absence of the sitting NI Assembly.

Most notably, the marriage equality campaign continuously lobbied for reform of the powersharing core institution, the Petition of Concern, in light of its past use to prevent the passage of marriage equality legislation. Here, we witness campaigning on issues relating to challenges of representation in divided society and the reform of power-sharing institutions similar to those voiced by plenums in $\mathrm{FBiH}$, but in a much more focused form. To do so, NEP relied almost entirely on the institutionalized avenues to advance its agenda not by translating its leverage into electoral politics, but by going beyond and above the powersharing institutions. The LGBTQ issues and NEP around marriage equality in NI was "not just about achieving for us, it's about achieving a different type of society and that means better rights and choices for women, greater diversity of expression" (Representative of LGBTQ Advocacy Group, 2018).

Whilst the increase in NEP around the LGBTQ issues in many ways mapped onto and reinforced the sectarian divide in NI, it opened the possibility of discourses alternative to ethno-national voter/party alignment. The interviewed activists and political representatives alike consistently referred to the tangible potential for an increase in cross-ethnic voting, for example, voters from a traditionally unionist background voting for nationalist SF as a reward for that party's progressive stance on LGBTQ issues. Yet, some observe the curious phenomenon of, "people who'll come to you at an LGBTQ protest or go to an Alliance for Choice event and then go and vote for the DUP the next day" (Representative of LGBTQ Advocacy Group, 2018). This might suggest that voters (continue to) place issues of LGBTQ rights in the social domain, rather than in the political one where ethnic identities determine electoral choices. The May 2019 NI local elections showcased the accomplishments of longterm mobilization for LGBTQ equality and sustained role of ethnic identities in formal politics when the first openly gay DUP candidate was elected, marking a "watershed change" for the party (BBC 2019). This success follows only three years after the party championing the LGBTQ agenda, NI Greens has placed a transgender activist on top of their electoral list in West Belfast for the Assembly elections in 2016. 
Following the 2017 NI Assembly election, NI political representatives failed to form government by the deadline of 21 October 2019 set by the national government as Northern Ireland (Executive Formation) Act 2019. This ensured that same-sex marriage will be legally recognized in NI by 13 January 2020, the ultimate objective of the marriage equality campaign.

\section{Discussion}

We have discussed how the citizens who perceive their primary political interests to have been sidelined in consociational settlements engage in NEP to redress the marginalization of their interest in the cases of FBiH and NI. Our outline above has suggested that the institutional background in which cross-community mobilization emerges - the social institutions that determine processes of identity formation and the political institutions that point towards specific types of interests that can be represented in the political process - are good predictors for NEP strategies. We found an apparent "blockage" in the political system for the advancement of civic and socially progressive issues in line with the inherent conservatism of power-sharing systems as a number of scholars have pointed out earlier. Nagle refers to the tendency for Lebanon's power-sharing system to empower ethnic hardliners opposed to sexual minorities (2018), while Thomson questions whether transitional systems are more "reticent" to produce socially progressive legislation (2016, 496).

The cases of FBiH and NI provide support for this point, given their imperviousness to wider socio-cultural shifts due to deep seated division in societies and consociational form of government in place. Since power-sharing has foreclosed formal avenues for political representation of interest not aligned with either of the constitutionally recognized communities, the focus on protest and later, bottom-up and participatory forms of political engagement has been the key in both cases. One of the LGBTQ campaigners interviewed, identifies the design of Northern Ireland's power-sharing system as lying at the "root of the problem". Here, ensuring continuous visibility of other identities has been essentially akin to political education in society, "changing the conversation around rights and participative democracy in Northern Ireland" (Representative of LGBTQ Advocacy Group, 2018). Likewise, Bosnian activists acknowledge to view nonelectoral mobilization as a step of the process for civic education and trust building across diverse groups in society (Kurtović 2018; Belyaeva 2017; Hasić and Karabegović 2018). They characterize this long-term shift in 
civic consciousness as their core goal, as opposed to short-term political change. Whilst this shift had not resulted in a change in electoral outcomes and institutional politics from the bottom-up, some observers believe that it has the potential to do so over time (Murtagh 2015; Milan 2017; Sircar 2019). Indeed, popular support for marriage equality legislation reflects the changing public attitudes in NI, the successful cooperation of the LGBTQ groups with the provincial and national policymakers, as well as the public indignation at the abuse of the Petition of Concern in the Northern Ireland Assembly. However, this shift in public opinions so far proves insufficient for reconfiguring preferred modes of political participation away from ethnic towards civic agendas.

NEP in both our cases allowed the exploit of various sources of division that exist in societies, from class to religion and ethnicity that have been hard to bridge in electoral politics. These divisions were politically salient in the past, but have become less relevant in the light of the everyday concerns that citizens shared regardless of their institutionalized political identities. As discussed, NEP in FBiH and NI societies has been triggered by concerns that identity politics are unable to deliver policies relevant for individuals who identify as citizens, in addition to - or instead of - politically relevant category of ethnicity. Mapping the grievances that transcend ethnic identities onto entire citizenry has allowed protest movements to mobilize and air the sense of mistrust in political institutions' ability to deliver policies that are not couched in categories centered on ethnic groups. In both our cases, the set of concerns expressed via NEP shows that the political participation and representation on the basis of identity were deemed insufficient by at least a part of the population in $\mathrm{FBiH}$ and NI.

In examining the relationship between consociational power-sharing and NEP, the cases of $\mathrm{NI}$ and $\mathrm{FBiH}$ demonstrate the consequences of engagement with issues and interests that did not map onto the main ethno-political cleavage. We therefore believe that - at least in the cases described - NEP can be viewed as a process of bottom-up re-construction of political process by the citizens of consociations refusing to co-operate on an exclusive, ethnic basis. The implicit exclusion of interests that are not clearly attributed to the politically salient identity groups offered the required incentive for mobilization. Critically, we observe in both $\mathrm{FBiH}$ and in NI that citizens rallying around socially relevant issues and identities tackled two issues: firstly, they challenged the perception that the ethnicity-based representation in place is effective and, secondly, they translated emergent alternatives into options to be taken seriously by those already part of formal political process. 
Firstly, we considered the context of consociational power-sharing and the ways in which these structures encouraged the NEP, which served as an alternative avenue to formal politics. The emergence of protest in both cases reflected a blockage within that system to the progression of issues affecting all citizens. This is more evident in the case of Bosnia where the blockage is more severe and, consequently, the plenums took a more radical rejection of formal politics in comparison to NI. We thus conclude that the openness of input structures in liberal and corporate consociations differ and determine whether NEP changes track from protest to organized alliances of NGO, and cooperation with political parties. Here, our findings demonstrate a contrast in the approaches of post-protest NEP in each case. While the marriage equality in Northern Ireland opted to engage directly - albeit cautiously - with political issues, actors and institutions, the plenums in Bosnia continued with only highly restricted engagement with formal politics. The NEP offers citizens of consociations one of the few possibilities for representation of those interests implicitly side-lined in politics. In the hindsight, as the elation in $\mathrm{FBiH}$ withered, plenums reconfirmed civic concerns in interactions with their members, but distanced themselves from the formal political process deeming civic interests less relevant for policymakers.

Secondly, it is worth considering the wider consequences of NEP on output capacity of political process serving divided societies. Our discussion suggests that identity-based divisions between the citizens continue to override concerns for civic issues (such as LGBTQ rights) and inclusive identities (such as citizens of $\mathrm{NI}$ or $\mathrm{FBiH}$ ), at least at the ballot box. This ethnic alignment between voters and elites require realistic and strategic commitment of those involved in NEP to engage with decision-makers and settling for incremental progress, rather than landslide change of formal political process. In NI, we witness a stronger and more explicit attempt to effect change on both the institutional and societal levels. At the level of society, activists describe an increase in acceptance of LGBTQ rights and endorsement of equal marriage as a discernible by-product of the grass-root campaign. At the level of institutional politics, this allowed the NEP focused on LGBTQ issues to organize groups and establish alliances, shifting the political discourse on representation and participation in power-sharing. In $\mathrm{FBiH}$, by contrast, the plenum's attempts to effect change in the formal political arena have been relatively limited, and, despite the activists' claim that a subtler and perhaps deeper shift in civic consciousness is under way as a result of NEP, today, one is uncertain of the consequences for formal political participation observable and attributable to protest and later plenum activities. 
The more radical form of NEP observed in the Bosnian case, was suggestive of public frustration with restricted opportunities for citizens' direct engagement with political process and limited in its potential to change the structure of decision-making. All these concerns reflect a higher degree of dysfunction and group institutionalization in the Dayton system. The reluctance to engage with formal politics in $\mathrm{FBiH}$ in comparison to NI, results from the higher (perceived) risks of co-optation faced by activists in the former framework. Nagle refers to the "identity dilemma" of LGBTQ activists in Lebanon, facing the choice of whether to construct a collective political identity and engage in the power-sharing system on this basis, or to reject collective identities and identity politics and oppose the power-sharing system $(2017,7)$.

These distinctions relate undoubtedly to the structural differences in input structures and output capacity of political process in each case, with deeper ethno-national commitment, polarization and a more pervasive culture of clientelism present in the Bosnian case. Though Bosnia's corporate consociational framework provides less space for the representation of civic rights and more "access points" to formal politics than the NI framework does, institutional differences, however, do not explain the disparity in consequences for citizen participation. The NEP in NI was different because the change in tactics from noncooperation with formal institutions to forming alliances with the NGOs and lobbying elites part of the NI political process, contained the dynamics of ethnicity based participation. The paper assessed the "conditions - consequences" link to compare and contrast, not to describe, the cases of cross-community NEP that - as scholarship tells us - are particularly hard to achieve in divided societies and in consociations. Citizen engagement in NEP can be observed in all types of polities: democratic and authoritarian, serving one and many ethnic communities, favoring group and those averse to group representation. Past studies have accounted for the ways in which civic mobilization took place, the social and political background in which nonelectoral participation unfolded, protests' repertoires of action, frames of reference, and organizational models (Milan 2017; Nagle and Fakhoury 2018; Touquet and Vermeersch 2016). However, there has been little analysis of mechanisms allowing NEP to amend the structure of political decision-making in consociational, deeply divided societies.

The account of NEPs in NI and FBiH is likely to appear sketchy, even superficial, to scholars interested in the detail of mobilization, its outcomes and effects in any one of our cases. But by mapping the choices of those involved in nonelectoral participation in order to transform 
their "issues" into "agendas", the paper offers an explanation "why", not "how" one type of NEP was able to achieve some of the originally aspired change, maintain and broaden support for the "original cause", where in another context NEP pitted out. We underline the importance of changing tracks in NEP once the protests reach their pick of mobilization. At a minimum, this promotes awareness about an overriding importance of citizens' other, nonethnic identities and, at maximum, leads to institutional reform broadening understanding of what constitutes political participation in divided places.

\section{Acknowledgements}

[redacted for peer review]

\section{References}

Agarin, Timofey. 2020. 'The Limits of Inclusion: Representation of Minority and NonDominant Communities in Consociational and Liberal Democracies'. International Political Science Review, 41 (1)

Agarin, Timofey, Allison McCulloch, and Cera Murtagh. 2018. 'Others in Deeply Divided Societies: A Research Agenda'. Nationalism and Ethnic Politics 24 (3): 299-310. https://doi.org/10.1080/13537113.2018.1489488.

Armakolas, Ioannis, and Maja Maksimovic. 2013. "Babylution” A Civic Awakening in Bosnia and Herzegovina?' Hellenic Foundation for European and Foreign Policy 34: 3-11.

Arsenijević, Damir, ed. 2014. Unbribable Bosnia and Herzegovina: The Struggle for the Commons. Baden-Baden: Nomos.

BBC 2019, NI council elections: First openly-gay DUP candidate elected, 4 May 2019, https://www.bbc.com/news/uk-northern-ireland-politics-47969822

Beichelt, Timm, Irene Hahn, Frank Schimmelfennig, and Susann Worschech. 2014. Civil Society and Democracy Promotion. Springer.

Belyaeva, Nina. 2017. 'Citizen Plenums in Bosnia Protests: Creating a Post-Ethnic Identity'. In Non-Western Social Movements and Participatory Democracy, 115-38. Springer.

Benford, Robert D., and David A. Snow. 2000. 'Framing Processes and Social Movements: An Overview and Assessment'. Annual Review of Sociology 26: 611-39.

Bieber, Florian. 2004. 'Power Sharing as Ethnic Representation in Postconflict Societies: The Cases of Bosnia, Macedonia, and Kosovo'. Nationalism after Communism: Lessons Learned, 231-48.

Bieber, Florian.2006. 'Bosnia-Herzegovina: Slow Progress towards a Functional State'. Southeast European and Black Sea Studies 6 (1): 43-64.

Bogaards, Matthijs. 2019. 'Formal and Informal Consociational Institutions: A Comparison of the National Pact and the Taif Agreement in Lebanon'. Nationalism and Ethnic Politics 25 (1): 27-42. https://doi.org/10.1080/13537113.2019.1565176.

Bojicic-Dzelilovic, Vesna, James Ker-Lindsay, and Denisa Kostovicova. 2013. Civil Society and Transitions in the Western Balkans. Springer.

Bosi, Lorenzo, and Gianluca De Fazio. 2017. The Troubles in Northern Ireland and Theories of Social Movements. Amsterdam University Press. 
Byrne, Sean. 2001. 'Consociational and Civic Society Approaches to Peacebuilding in Northern Ireland'. Journal of Peace Research 38 (3): 327-52.

Ceka, Besir. 2018. 'Macedonia: A New Beginning?' Journal of Democracy 29 (2): 143-57.

Della Porta, Donatella, and Sidney Tarrow. 1986. 'Unwanted Children: Political Violence and the Cycle of Protest in Italy, 1966-1973.' European Journal of Political Research 14 (5-6): 607-632.

Della Porta, Donatella, ed. 2017. Global Diffusion of Protest: Riding the Protest Wave in the Neoliberal Crisis. Amsterdam University Press.

Di Palma, Giuseppe. 1991. 'Legitimation from the Top to Civil Society: Politico-Cultural Change in Eastern Europe'. World Politics 44 (1): 49-80.

Eisinger, Peter K. 1973. 'The Conditions of Protest Behavior in American Cities.' American Political Science Review 67 (1): 11-28.

Evans, Jocelyn, and Jonathan Tonge. 2016. 'Partisan and Religious Drivers of Moral Conservatism: Same-Sex Marriage and Abortion in Northern Ireland'. Party Politics,.

Fligstein, N., \& McAdam, D. 2015. A Theory of Fields. Oxford: Oxford University Press.

Forde, Susan. 2016. 'The Bridge on the Neretva: Stari Most as a Stage of Memory in PostConflict Mostar, Bosnia-Herzegovina'. Cooperation and Conflict 51 (4): 467-83. https://doi.org/10.1177/0010836716652430.

Fraenkel, Jon. 2020. 'The "Uncle Tom" Dilemma: Minorities in Power-Sharing Arrangements'. International Political Science Review 41 (1).

Glenn, John K. 2003. 'Contentious Politics and Democratization: Comparing the Impact of Social Movements on the Fall of Communism in Eastern Europe'. Political Studies 51 (1): 103-20.

Gordy, Eric. 2015. 'From Antipolitics to Alterpolitics: Subverting Ethnokleptocracy in Bosnia and Hercegovina'. In Unbribable Bosnia: The Fight for the Commons, edited by Damir Arsenijevic, 111-18. Baden-Baden: Nomos Verlagsgesellschaft.

Graziadei, Stefan. 2016. 'Democracy v Human Rights? The Strasbourg Court and the Challenge of Power Sharing'. European Constitutional Law Review 12 (1): 54-84.

Hartzell, Caroline, and Matthew Hoddie. 2003. 'Institutionalizing Peace: Power Sharing and Post-civil War Conflict Management'. American Journal of Political Science 47 (2): 318-32.

Hasić, Jasmin, and Dženeta Karabegović. 2018. 'Elite Responses to Contentious Politics on the Subnational Level: The 2014 Bosnian Protests'. Southeast European and Black Sea Studies 18 (3): 367-80.

Horowitz, Donald L. 1985. Ethnic Groups in Conflict. Berkeley London: University of California Press.

Irish Times. 2017. 'Sinn Féin Withdraws from Stormont Negotiations'. The Irish Times, 26 March 2017. https://www.irishtimes.com/news/politics/sinn-f\%C3\%A9in-withdrawsfrom-stormont-negotiations-1.3025247.

Jasper, J. M., \& Duyvendak, J. W. eds. 2015. Players and Arenas: The Interactive Dynamics of Protest. Amsterdam University Press.

Johnston, Hank, and John A. Noakes. 2005. Frames of Protest: Social Movements and the Framing Perspective. Rowman \& Littlefield Publishers.

Jusić, Mirna, and Nenad Stojanović. 2015. 'Minority Rights and Realpolitik: Justice-Based vs. Pragmatic Arguments for Reserving Seats for National Minorities'. Ethnopolitics 14 (4): 404-17.

Keil, Soeren. 2013. 'Europeanization, State-Building and Democratization in the Western Balkans'. Nationalities Papers 41 (3): 343-53. 
Kennedy, Ronan, Claire Pierson, and Jennifer Thomson. 2016. 'Challenging Identity Hierarchies: Gender and Consociational Power-Sharing'. The British Journal of Politics and International Relations 18 (3): 618-33.

Khneisser, Mona. 2018. 'The Marketing of Protest and Antimonies of Collective Organization in Lebanon'. Critical Sociology, September, https://doi.org/10.1177/0896920518792069.

Kitschelt, H. 1986. 'Political Opportunity Structures and Political Protest: Anti-Nuclear Movements in four Democracies'. British Journal of Political Science, 16 1, 57-85.

Kriesi, Hanspeter, Ruud Koopmans, Jan Willem Duyvendak, and Marco G. Giugni. New social movements in Western Europe: A comparative analysis. Routledge, 2015.

Kriesi, Hanspeter. 'Political Context and Opportunity.' The Blackwell Companion to Social Movements (2004): 67-90.

Kurtović, Larisa. 2018. 'Conjuring "the People”". Focaal 2018 (80): 43-62.

Kurtović, Larisa, and Azra Hromadžić. 2017. 'Cannibal States, Empty Bellies: Protest, History and Political Imagination in Post-Dayton Bosnia'. Critique of Anthropology 37 (3): 262-96.

Lai, Daniela. 2019. 'Practicing Solidarity: 'Reconciliation'and Bosnian Protest Movements'. Ethnopolitics, 1-20.

Luther, Kurt Richard, and Kris Deschouwer. 1999. Party Elites in Divided Societies: Political Parties in Consociational Democracy. Routledge.

McCulloch, Allison. 2012. 'Does Moderation Pay? Centripetalism in Deeply Divided Societies'. Ethnopolitics 12 (2): 111-32.

McCulloch, Allison. 2014. 'Consociational Settlements in Deeply Divided Societies: The Liberal-Corporate Distinction'. Democratization 21 (3): 501-18.

McEvoy, Joanne. 2014. Power-Sharing Executives: Governing in Bosnia, Macedonia, and Northern Ireland. University of Pennsylvania Press.

McFaul, Michael, and Elina Treyger. 2004. 'Civil Society'. In Between Dictatorship and Democracy. Russian Post-Communist Political Reform, edited by Michael McFaul, Nikolai Petrov, and Andrei Ryabov, 135-73. Washington D.C.: Carnegie Endowment For International Peace.

Meyer, David S. 2004. 'Protest and Political Opportunities.' Annual Review of Sociology. 30: 125-145.

Milan, Chiara. 2017. 'Reshaping Citizenship through Collective Action: Performative and Prefigurative Practices in the 2013-2014 Cycle of Contention in Bosnia \& Hercegovina'. Europe-Asia Studies 69 (9): 1346-61.

Milan, Chiara. 2018. 'Bosnia and Herzegovina: From Workers' Strike to Social Uprising'. In The Class Strikes Back, 155-75. Brill.

Mitchell, David. 2018. 'Non-Nationalist Politics in a Bi-National Consociation: The Case of the Alliance Party of Northern Ireland'. Nationalism and Ethnic Politics 24 (3): 33647.

Mujkić, Asim. 2014a. 'Bosnian Days of Reckoning: Review of the Sequence of Protests in Bosnia and Herzegovina 2013-14'. Southeastern Europe, 40(2), 217-242.

Mujkić, Asim. 2014b. 'The Evolution of Bosnia and Herzegovina's Protests in Five Theses'. In Unbribable Bosnia: The Fight for the Commons, 119-34. Nomos.

Murtagh, Cera. 2015. 'Reaching across: Institutional Barriers to Cross-Ethnic Parties in PostConflict Societies and the Case of Northern Ireland'. Nations and Nationalism 21 (3): 544-65.

Murtagh, Cera. 2016. 'Civic Mobilization in Divided Societies and the Perils of Political Engagement: Bosnia and Herzegovina's Protest and Plenum Movement'. Nationalism and Ethnic Politics 22 (2): 149-71. 
Murtagh, Cera. 2020. 'The Plight of Civic Parties in Divided Societies'. International Political Science Review 41 (1).

Nagle, John, and Mary-Alice C. Clancy. 2012. 'Constructing a Shared Public Identity in

Ethno Nationally Divided Societies: Comparing Consociational and Transformationist Perspectives'. Nations and Nationalism 18 (1): 78-97.

Nagle, John, and Tamirace Fakhoury. 2018. 'Between Co-Option and Radical Opposition: A Comparative Analysis of Power-Sharing on Gender Equality and LGBTQ Rights in Northern Ireland and Lebanon'. Nationalism and Ethnic Politics 24 (1): 82-99.

Nagle, John. 2018a. 'Beyond Ethnic Entrenchment and Amelioration: An Analysis of NonSectarian Social Movements and Lebanon's Consociationalism'. Ethnic and Racial Studies 41 (7): 1370-89.

Nagle, John. 2018b. 'Crafting Radical Opposition or Reproducing Homonormativity? Consociationalism and LGBT Rights Activism in Lebanon'. Journal of Human Rights 17 (1): 75-88.

Noel, Sid. 2005. 'From Power Sharing to Democracy'. Post-Conflict Institutions in Ethnically Divided Societies, Montreal

O'Flynn, Ian. 2003. 'The Problem of Recognising Individual and National Identities: A Liberal Critique of the Belfast Agreement'. Critical Review of International Social and Political Philosophy 6 (3): 129-53.

Oberschall, A. 1973. Social Conflict and Social Movements. Englewood Cliffs.

Piacentini, Arianna. 2019. "Trying to Fit In": Multiethnic Parties, Ethno-Clientelism, and Power-Sharing in Bosnia and Herzegovina and Macedonia'. Nationalism and Ethnic Politics 25 (3): 273-91.

Pickvance, Christopher G. 1999. 'Democratisation and the Decline of Social Movements: The Effects of Regime Change on Collective Action in Eastern Europe, Southern Europe and Latin America'. Sociology 33 (2): 353-72.

Polletta, Francesca, and James M. Jasper. 2001. 'Collective Identity and Social Movements'. Annual Review of Sociology 27 (1): 283-305.

Pollozhani, Lura. 2016. 'The Student Movement in Macedonia 2014-2016'. Südosteuropa Mitteilungen, no. 05-06: 38-45.

Powell, G. Bingham, 2000. Elections as Instruments of Democracy. Yale University Press.

Puljek-Shank, Randall, and Willemijn Verkoren. 2017. 'Civil Society in a Divided Society: Linking Legitimacy and Ethnicness of Civil Society Organizations in BosniaHerzegovina'. Cooperation and Conflict 52 (2): 184-202.

Riding, James. 2018. 'A new regional geography of a revolution: Bosnia's plenum movement.' Territory, Politics, Governance 6(1): 16-41.

Sircar, Indraneel. 2019. 'Linking Active and Activist Citizens: Electoral Change and the Bosnian Plenums'. Journal of Elections, Public Opinion and Parties, 1-21.

Stojanović, Nenad. 2017. 'Political Marginalization of "Others" in Consociational Regimes'. Zeitschrift Für Vergleichende Politikwissenschaft, 1-24.

Tarrow, Sidney. 1989. 'Power in Movement: Social Movements and Contentious Politics. Cambridge.' Cambridge University Press.

Tarrow, Sidney. 1993. 'Cycles of Collective Action: Between Moments of Madness and the Repertoire of Contention.' Social Science History 17, 2: 281-307.

Tarrow, Sidney, and Charles Tilly. 2007. 'Contentious Politics and Social Movements'. In The Oxford Handbook of Comparative Politics.

Taylor, Rupert. 2009. 'The Injustice of a Consociational Solution to the Northern Ireland Problem'. Consociational Theory: McGarry and O'Leary and the Northern Ireland Conflict, 309-29. 
Thomson, Jennifer. 2016. 'Abortion and Same-Sex Marriage: How Are Non-Sectarian Controversial Issues Discussed in Northern Irish Politics?' Irish Political Studies 31 (4): 483-501.

Touquet, Heleen, and Peter Vermeersch. 2016. 'Changing Frames of Reconciliation The Politics of Peace-Building in the Former Yugoslavia'. East European Politics \& Societies 30 (1): 55-73.

Touquet, Heleen. 2015. 'Non-Ethnic Mobilisation in Deeply Divided Societies, the Case of the Sarajevo Protests'. Europe-Asia Studies 67 (3): 388-408. https://doi.org/10.1080/09668136.2015.1019430.

Van der Meer, Tom WG, Jan W. Van Deth, and Peer LH Scheepers. 2009. 'The Politicized Participant: Ideology and Political Action in 20 democracies.' Comparative Political Studies 42, 11: 1426-1457.

Verba, Sidney, Kay Lehman Schlozman, and Henry E. Brady.1995. Voice and Equality: Civic Voluntarism in American Politics. Harvard University Press.

Verba, Sidney, Norman H. Nie, and Jae-on Kim. 1978. A Seven Nation Comparison: Participation and Political Equality. Cambridge.

Vráblíková, Kateřina. 2014. 'How Context Matters? Mobilization, Political Opportunity Structures, and Nonelectoral Political Participation in Old and New Democracies.' Comparative Political Studies 47, 2: 203-229. 